ANDRZEJ SZPULAK

Institute of Film, Media and Audiovisual Arts Adam Mickiewicz University in Poznań

\section{View from the inside. The images of the city in the "black series" documentary films in Poland in the 1950s}

\begin{abstract}
Aвstract. Szpulak Andrzej, View from the inside. The images of the city in the "black series" documentary films in Poland in the 1950s. "Images" vol. XXII, no. 31. Poznań 2017. Adam Mickiewicz University Press. Pp. 113-122. ISSN 1731-450X. DOI 10.14746/i.2017.31.11.

The article analyses the particular interest that the documentary filmmakers of the late 1950s had in the architectural and urban issues. The reasons for this phenomenon are situated in several plans: they refer to the image of reconstruction from the war devastation and the reaction to its falsification in the period of socialist realism. They refer to the social interests of the filmmakers and to the strategy of metaphorising and allegorising the images of the city, which was handy in the times of censorship as it extended meanings and applied non-literality. The article analyses various film incarnations of this phenomenon.
\end{abstract}

KEYWORDs: film and architecture, "black series" of Polish documentary, Polish documentary, Jerzy Bossak, Irena Sobierajska, Bohdan Kosiński, Jerzy Dmowski, Kazimierz Karabasz, Władysław Ślesicki, Krystyna Gryczełowska, Maksymilian Wrocławski, Andrzej Munk

World War II was a time of total destruction for Poland, including the material substance of its cities. It is hardly surprising that in the years immediately after the war, and the second half of the 1950s, which make the chronological background for my work, belong to this period. Architectural and urban issues occupied an important place in Polish public life, and with their visual attractiveness and a connection to burning social issues they attracted the attention of documentary filmmakers. It is not surprising that in the previous period, i.e. at the end of the 40 and the first half of the next decade, the communist government only allowed a statements to circulate that expressed the delight at the progress and quality of reconstruction and the modernity of the construction projects implemented by them. The camera was always set so that the lens did not reach to what violated the harmony of socialist realism, to what was disordered.

A good example is provided by Bolesław Michałek, when he refers to a scene from Ludwik Perski's film Warszawa, 1952-1954 [Warsaw]. It is a film full of well selected and prepared images of reconstructed Warsaw, usually very static. These include of the Castle Square with the Sigismund's Column, which has been raised from ruin, towering over it. "If, however, we moved the camera about two degrees to the right, we would see on the screen the ruins of the Royal Castle, and a mess
Images vol. XXII/no. 31 Special Issue Poznań 2017 ISSN 1731-45OX 
at the end of Piwna and Świętojańska Street." But when attempting this kind of movement, "the camera would automatically turn off".[1]

The response to such poster-like forging of reality had to appear at the time of Polish October Thaw, and it appeared mainly in films belonging to the "black series" of Polish documentaries. One might be surprised not so much by the mere presence of the interesting topics but by the intensity of the presence and the rank given to them, which came out far beyond the standard framework.

This involved, of course, the fact that, although in the late 1950 s the conditions of censorship clearly changed in favour of the creators, the door to the truth was only left ajar. All the most dramatic issues, linked to the activities of the so called ministry, remained beyond the scope of filmmakers' exploration. Profound criticism of the given reality from young documentary filmmakers, the ones who contributed to this trend, had to be aimed at something, to be somehow channelled. Social issues became an acceptable space for that: the superficiality of the propaganda image of the world, the real living conditions in Poland and the difficult situation of the young generation. Images of cities and towns, individual districts, major buildings, households proved to be excellent visual media for the critical content. They did not talk only about themselves, but also symbolized, or rather allegorised the experience of the dissonance between what the official propaganda talked about the life in communist Poland and what this life really was.

The directors' imagination was influenced by the Palace of Culture and Science opened in 1955, just stripped of the name of its patron and also the originator, Joseph Stalin. Obviously, the very fact of its construction and the presence in the centre of Warsaw was not - as it happens today, openly contested. But it appeared in many films as a visual sign of the most important antithesis for that cinema, which may be summarized as the contrast between the exposed facade, and the concealed interior. It acted as, of course, the sign of the first part.

It is shown in this function by the patron of young documentary filmmakers, Jerzy Bossak, in Warszawa 1956 [Warsaw 1956], but also by a student of Łódź Film School, Irena Sobierajska, in the short film Żebracy [Beggars] (1956), expressing the same sentiments that prevailed in the works of older colleagues from the group of the "black series". Two years later, Bohdan Kosiński and Jerzy Dmowski repeat that in Miasto na wyspach [The City on the Islands] (1958).

A fragment of the commentary for the film by Bossak explains the issue explicitly. Moreover, this practice of literalism was appropriate for the majority of those movies.

A chronicler counts new houses, new squares, new estates and playgrounds. Writes down Warsaw songs. And waits patiently until the sun most beautifully decorates the facades of Warsaw's palaces. But 1956 is different from

[1] B. Michałek, Szkice o filmie polskim, Warszawa

1960, p. 22. 
previous years. The chronicler looks carefully and sees what they previously tried not to notice

- these words can be heard from the screen. And from the point at which there is the sentence about the palaces, the tallest building in the capital appears in in the frame, first viewed in monumentalising shots from the bottom, and a moment later in a distant plan as a backdrop to the image of a woman hanging laundry in a dilapidated residential building. In the following parts of the film we plunge into the lives of those ruins inhabited by poor families.

The image of beggars populating the city centre, which is crucial to the film by Sobierajska, was also paired with the frame highlighting the Palace. The poetics of contrast usually characterized the then critical documentaries, bearing the antithesis outlined above and present in them. So the image of the architectural pride of the decade became, I think, a little involuntary an allegory of lies, false description of reality, care about the condition of the facade, and the total neglect of what is under the surface.

This is slightly complicated in Miasto na wyspach [The Town on the Islands], the film entirely devoted to then contemporary issues of Warsaw urban planning. This time, the image of the Palace of Culture and Science was associated with two spaces, or in fact just one although divided in time. The palace first appeared before the series of filmed photographs. The commentary explains:

One hundred metres from the city's focal point [here a frame with the Palace - A.S.]. Year 1939. The camera is in the archives of photographs. The photographs show the old city centre in Warsaw. Here lived eight hundred thousand people, here was the centre which organized the city into one compact unit, here lay the most valuable areas of the city. It was only after they had been built up those that were further away were used. So logic dictated. 1944 destroyed the districts and prepared the most valuable areas of Warsaw for future development.

After this passage, the narrative returns to the same point, i.e. the frame with the Palace. The reader deliberately recites: "One hundred metres from the city's focal point [here is the frame - A.S.]. Year 1958. The camera is located in the centre of a city of one million inhabitants. Here's what it sees. "In the long, static shots, we can see great undeveloped spaces, filled with mud, bushes, power grid posts, here and there some rubble and ruins of buildings cut by empty, neglected streets along which a dog is wandering, and a lonely woman is walking with a stroller. And in the background, every now and again, the characteristic shape of the "gift of the Soviet people."

The main contrast is created here by the opposition of the images of the city centre before the war and that of 1958. It must be admitted that it is a very brave synthesis of the achievements of the Polish People's Republic. The Palace itself plays the role of the central point, which is characteristic and helps one to get one's bearings. But when it appears 
as a background of the current images of the city centre, it begins to convey a message proposed by Bossak and Sobierajska and it does it very clearly.

The visual essence of the facade-interior antithesis is constituted by a parallel present in the film which depicts neither the Palace of Culture and Science, nor even Warsaw. It is Lubelska starówka [Lublin Old Town] (1956) by Kosiński. This short, just a five-minute film starts with a long series of shots of Lublin market square. The eye of the camera contemplates the beautiful facades of sixteenth-century houses, renovated for the tenth anniversary of liberation. Then it focuses on the heavily staged tourist traffic and later moves rapidly to a backyard hidden from the eyes of visitors. We move from brightness to twilight, from the ordered space to its opposite, from the sense of solidity of the material structure of reality to the great uncertainty. Large amounts of garbage lying around and dirty children playing among it, a ladder instead of stairs, complex wooden structures which support collapsing ceilings in the interiors of the flats, these are the elements of the image of true ruins lurking a few dozen metres from the restorers' showpiece.

The word played its role as well. The column-style comment was seasoned with irony to the point that it lost its moralistic didacticism, so characteristic of those movies. The images were accompanied by a literary concept which consisted in affirmative comments on the appalling state of the buildings as being the result of the concern about preserving earlier forms of existence. While the camera is following a woman leaving a backyard and coming to the front of the striking facade of the house, the voice of the narrator concludes: "There are barbarians, who are demanding the renewal of the old town of Lublin, they want to destroy the patina of age and make the interior look like the facade. They do not understand that facades and interiors play completely different roles in our country." And referring to the final scene with a bugler, he adds: "There are those for whom the superficiality is a visual addition to blowing the trumpets. So let's keep blowing." One could hardly get a clearer outline of the intentions of the author and his black-series colleagues for whom the duality of the world in which they lived, and which they viewed, was a source of deep discomfort. At the same time, it was a rewarding material for practising film imagination.

The pervasive poetics of contrast served superbly to illustrate the effects of modernization, which interested the filmmakers. The first was shown by Kazimierz Karabasz and Władysław Slesicki in Gdzie diabet mówi dobranoc [Where the Devil Says Goodnight] (1956). It was a construction site of a cultural centre in Warsaw's Targówek, a neglected district with old, poor, sometimes wooden, rather not impressive, and to a great extent ruined buildings. It was a district devoid of modern conveniences - even if only in the form of a decent street lighting, and places of entertainment other than dirty pubs and a crowded mobile cinema. And this district was to receive a peculiar gift from the newly established authorities - the magnificent building of a cultural centre. The visual 
effect of this project was not convincing, as noted by the narrator, when the design drawings were placed in front of the camera. The massive walls of the socialist realistic building, clad in scaffolding, visible in the frame dominated the whole area and did not relate to its character. However, the film is not about the quality of architecture, but about unveiling the results of actions taken - actions which were to generate socio-moral changes, new forms of life of the local community, above all its youth. After eight years of increasingly sluggish work, the underinvested construction was finally stopped. There was just one small gym opened, which was supposed to accommodate all diverse activities, and the powerful, poorly protected building entered a phase of degradation. This is is the state in which the camera observes the building - unfinished and decaying. "Here, too, there was supposed to be a palace of culture. It has been forgotten", says the narrator, referring this time only verbally, to the emblem of the passing era which awakens so many emotions.

This film is, of course, intervention material. It is a synthetic comment on reality. The image of an unfinished construction, as well as on-screen parallel of facades and interiors, had an extended semantic field. It became the image, allegorical in its nature, of the achievements of Polish Stalinism, and especially its social aspect. In this case, the facade did not even appear.

The issue of the devastation of the achievements of a doctor and architect, Dr. Bałasz, in the village of Siedliszcze located near Chełm (east of Poland), is a slightly different case. This film by Krystyna Gryczełowska Siedliszcze (1960) was again based on a contrasting parallel. The first part is a quotation from Polish Film Chronicle footage dating from 1954. It concerned the effects of the actions of a remarkable social worker, who could infect everyone with his activity and induce the cooperation of villagers and distant provincial authorities. This resulted in a wealth of infrastructure unusual, in a Polish village of that time: pavements, a drainage ditch, a swimming pool, a sports club, a hospital, and there were plans to build a marmalade factory. The director decided to call: I check. She confronted the archive material with the then current image of the time, filmed by her in Siedliszcze four years after the departure of Dr. Bałasz for Kraków. This fragment consists of scenes presenting deserted and devastated, or even looted, buildings, and comments from community members who are fairly clumsy in attempting to explain what had happened. The film affirms social activity, subtly accusing the local people and authorities. But above all, it ascertains the lack of systemic praxis. The whole project becomes possible only because there is a person with special abilities, will power and persuasion, and it lasts only for as long as the person is present there. The planned, consistently carried out modernization - as in the case of Gdzie diabeł mówi dobranoc [Where the Devil Says Goodnight] - turns out to be an illusion.

The "black series" films are very keen on focusing on issues concerning the existence of the young, their living conditions and the 
prospects of adult life on an appropriate moral and material level. It would seem that the issues referred to in this text can be associated with those aspects in one fundamental way. It is, of course, about the housing problems. They were so poignant that they even appeared in comedy feature films. In a documentary they could be taken as much more dramatic.

They are indeed ubiquitous. After all, they appear in Lubelska starówka [Lublin Old Town], Warszawa 1956 [Warsaw 1956], where he staged the scene with a baby balancing on the edge of life and death, or in Miasteczko (1956) [Small Town] by Jerzy Ziarnik. We follow the baby snapping the string with which it was tied to a bed by the mother who was doing the laundry. It is not, however, about the pathology of the family, but about the fact that just outside the door of this one-bedroom flat there is a "staircase," the state of which gives the toddler all chances to fall into the abyss of a few meters. By incident, the tragedy does not occur: it was staged by the filmmakers.

Scary, or at least very poor housing conditions are the leitmotif of those films, a sort of permanent landscape. But in the case of young people we are faced with something more. Our attention is drawn to the effect of strangeness appearing between them and the space of the city. It looks as if they could not find their place in it. Cramped housing, in which we are struck by the lack of freedom or room for your own privacy, let alone meetings with peers and social life, is one thing. We observe such a situation in the case of one of the heroines of Ludzie $z$ pustego obszaru (1957) [People from an Empty Area] by Karabasz and Ślesicki, a film dedicated to youth. But a more interesting thing is the perceived mismatch between their needs, way of life and the surrounding space, or even processing or perverting this way of existence, precisely because of this mismatch.

The heroes, somehow at a push, adapt some space for themselves, quite contrary to its original purpose. This happens in the vicinity of the monument of "the four sleepers," the same which, after long discussions, disappeared from Wileński Square, in 2011 probably for good. But above all, they choose a place that is marginal, undeveloped, and unfriendly from the urban point of view. Among these wastelands, which an average resident would typically associate primarily with danger, which were hidden from the adults, and even from seemingly ubiquitous law enforcement officers, the heroes perform their staged, youthful initiations. This happens without any rules, because the adult world has nothing to offer here, also in the sense of urban space. The empty area from the title, which offers multi-level interpretative possibilities, also refers precisely to the situation of the mismatch between the heroes and their surroundings, the situation already outlined in the previous film by these authors, which had been devoted to Targówek.

Among the "black series" productions there is a film which was entirely devoted to the problem we are interested in. This is indicated by its very title - Miejsce zamieszkania [Place of Residence]. This doc- 
umentary was made by Maksymilian Wrocławski in 1957 in Kraków, in fact in Pleszów, a housing estate for the builders of Nowa Huta. The author meticulously ( at fifteen minutes this is the longest film in the "black series") and analytically looks at the local people (mostly the young) and the conditions of their lives, contrasting their fate with the announcement (the voice of the announcer in the first scene conjures up an ideal vision of workers' livelihoods) and the image created by officials, or journalists (the scene showing a friendly chat between the two groups). It compares the state of the housing development in Pleszów and the living conditions of 1954 with that of its time, three years later. The opposition, from which it is difficult to escape in this text, is imposed again: facade-interior. The director looks inside the propaganda messages.

In the first scenes on the screen we can see workers cooking soup on a campfire blazing among the thicket. These are Pleszów residents, young men who have come to the big construction site, usually from villages. Under the conditions proposed to them, i.e. in makeshift huts with bunk beds, without any comforts, built along the muddy streets, without any meaningful access to appropriate and valuable entertainment (still the only place is a crowded off-licence), with no prospect of improving their conditions, they turn into dangerous people, a kind of lumpen proletariat.

Starting a family does not offer any chance in this situation. After all, we can watch the situation of a marital rift. The wife gives her husband soup through the window of a female workers' hostel. The husband is unsuccessfully knocking at the door of the same hostel when his wife is giving birth. And finally, we can see them strolling in the late autumn rain and mud, in a place that gives them a unique opportunity for a more intimate encounter. What has been built seems in this case to exist against people. When finally they receive a chance to live together, it is in a "modern" block with one kitchen for forty flats. The improvement, which after three years is achieved by only a relatively few lucky people, turns out to be largely illusory.

However, on the outskirts of the "black series," there is a film that treated the matter of the city in a different way, though the camera was operating in a district which was just as "picturesque" as Targówek. The social demands became less important. The emphasis was placed on evoking the mood and on discovering the specific aesthetics of the place. The film in question here is Z Powiśla [From Powiśle] (1958) by Kazimierz Karabasz.

That film was assumed to be a static image of life of people blended in the space that was ruined by the war, neglected, marginalized, this time, however, not undergoing the critical overview, seen with some degree of infatuation. We see the world and the manifestations of life existing in their own, slow pace, allowing us to look into the time before the disaster of the war elsewhere long gone. In full sunlight the lens moves through the narrow streets, battered facades of houses, the 
courtyards and outbuildings standing in them. It looks at the statue of the Warsaw Mermaid, hospital buildings in Solec, gates, fields of ruins. Sometimes, in the background, it catches sight of new buildings in the city centre where the modern diversity makes the old Powiśle even more autonomous. "The city stopped there, in higher parts, as if afraid to go lower", concludes the narrator. He seems to be calling for change, but, together with the camera, he is in fact fascinated with the place that is frozen in time. Wounded by war, lonely, as if congealed in expectation, as he says. It is a quiet, against the propagated spirit of the time - the time of industrialization and dynamic urbanization - apotheosis of what is departing, ignored, also of the material substance of the city, which seems to be its shameful part.

Andrzej Munk's view in Spacerek staromiejski [A Stroll in the Old Town] (1958) is similar. Certainly the film does not belong to the "black series," and it is even difficult to qualify it as a documentary. But it is worth mentioning for two reasons. The first is a certain similarity to the film by Karabasz. And the second - the specific presence of the Palace of Culture. Anyway, both reasons connect very harmoniously.

Munk, sending his little heroine on a musical stroll on a sunny day, makes her move not into the picturesque, although somewhat rundown part of Powiśle, but into its respectable part, mostly just restored to its proper appearance after wartime destruction. But, undoubtedly, one of his goals was to bring out the atmosphere of the place, including its distinctive architecture. In the final part of the film, just as it was with Karabasz, a strolling girl is seen among the ruins, perhaps even the same ruins. Again, we watch her as part of the aesthetic vision, and not as remorse.

The director's visual dedication to the world of old architectural forms also, as in Z Powiśla [From Powiśle], finds its counterpoint. In Munk's film it is the image of the Palace of Culture. The outline of the building is seen through a curtain in the school where the story begins. It is hazy, distant, as if completely cancelled, marginalized in view of the beauty of the Old Town. One can, I think, interpret such an operation as a discrete manifestation of incorrectness.

Of course, this is not only the film by the author of Zezowate szczęście [Bad Luck], although this one most creatively touches the subject which is of interest to us, at the moment of the success of the "black series" poetics in the late 1950s, and that has not much in common with this poetics. It was not only this film that refrained from following those black-series ways of seeing the world.

This context is worth a brief outline at the end. The films that were closest to those by Karabasz, Kosiński and their colleagues were those that touched the pressing social issues i.e. the housing problems (1 200000 izb [1 200 ooo Rooms] by Aleksander Minorski, 1956) or negligence. Those were purely intervention films. They had no deeper 
critical ambitions nor did they try to perform any deeper social penetration or any synthesis of reality.

There were also, because, obviously, there had to be, films that affirmed the process of post-war reconstruction. The filmmakers' and their principals' interest, for political reasons, was directed in this regard primarily to the areas in the west (Mój Szczecin [My Szczecin] by Witold Lesiewicz, 1955, Na przykład Kołobrzeg [For Example Kołobrzeg] by Jadwiga Plucińska, 1958, Nad Nysa, Odra i Battykiem [On the Neisse, the Oder and the Baltic Sea] by Wacław Kaźmierczak, 1958). There were the motifs of a revolution in housing construction which was expected to be brought about by concrete panel construction. This revolution was foretold in two films (Budownictwo [Construction], 1959, and Budownictwo wielkoptytowe [Panel Building], 1960) by Leonard Zajączkowski, perhaps best remembered as the cinematographer in Człowiek $z$ marmuru [Man of Marble] (1977) by Andrzej Wajda. Jan Łomnicki consistently recorded the construction of Nowa Huta in those years, and the series of his films includes also Narodziny miasta [The Birth of the City] (1959). There was also an attempt to outline the prospects of development through the contact with Western architecture, which was manifested by two films by Mieczysław Wiesiołek (Współczesna architektura francuska [Contemporary French Architecture], 1956, and Notatki o wspótczesnej architekturze Włoch [Notes on the Contemporary Architecture in Italy], 1958), through presentations of development projects in Warsaw in the film by Ludwik Perski $O$ Warszawie, ale inaczej [About Warsaw, but Otherwise] (1960), and finally, through a poster-like presentation of the idea of building for educational purposes (10oo szkót na tysiaclecie [1000 Schools for the Millennium] by Jerzy Kadena, 1959).

They shot at that time a lot of films about the old architecture of Polish cities and about the most important Polish monuments, many educational and tourist films. Typical representatives of that included coverage of Sandomierz Miasto na wzgórzach [The City on the Hills] (1956) by Tadeusz Jaworski, Dawny Toruń [Ancient Toruń] (1960) by Edward Pełczyński, Świątynia Mariacka w Krakowie [St. Mary’s Church in Kraków] (1960) by Zbigniew Bochenek. The most interesting were Żywe kamienie [Living Stones] by Tadeusz Makarczyński, devoted to Kraków’s Kazimierz district, or Warszawskie Łazienki [Łazienki Park in Warsaw] (1960) by Tadeusz Jaworski, an unusual film poetic form.

In most of these productions the issues of architecture appeared in a stereotypical way, which does not necessarily mean wrong way. It is difficult to negate making films devoted to sightseeing in a country with such a low level of tourist traffic as the Poland of that period, and in addition in the era before TV. It is even hard to criticise the productions. Against this background, however, the extraordinary importance given to the architecture and urban space by the "black series" films is even more evident. They did not have a particular or niche character, but they became pars pro toto. 
Fiejdasz M., "Czarna seria” w polskim filmie dokumentalnym, "Kwartalnik Filmowy" 1998, no. 23, pp. 42-61.

Historia polskiego filmu dokumentalnego, red. M. Hendrykowska, Poznań 2015

Iskierko A., Film dokumentalny, in: Historia filmu polskiego, t. IV: 1957-1961, red. J. Toeplitz, Warszawa 1980

Michałek B., Szkice o filmie polskim, Warszawa 1960

Nastałek-Żygadło G., Filmowy portret problemów społecznych w „czarnej serii” 1956-1958, Warszawa 2013

Preizner J., PRL w obiektywie łódzkiej Filmówki w latach 1949-1960, Kraków 2007 